\title{
PERAN PELIBATAN DIRI SISWA SEBAGAI MEDIATOR DALAM HUBUNGAN ANTARA IKLIM KELAS DENGAN SIKAP KREATIF SISWA SD SEKOLAH ALAM
}

\author{
Rafika Rahmi, Rose Mini Agoes Salim \\ Program Magister Ilmu Psikologi Pendidikan \\ Fakultas Psikologi \\ Universitas Indonesia \\ rafikarahmi11@gmail.com
}

\begin{abstract}
The aim of this study is to measure the role of student's school engagement as mediator in relations between classroom climate with creative attitude in nature-based school. The background of this research is the needs of creative attitude to face the challenge in the future by create the classroom climate and make the children more involved in school activity. One of the ways to increase creative attitude and school engagement is by creating the classroom climate that support the student's need. Nature-based school is one of alternative schools in Indonesia that creates active learning in their classroom climate that encourage students to be more engage, so therefore the students can have creative attitude. This research is done with quantitative methods and nonprobability sampling methods for elementary school students from grade 3 until 5 in one of Nature Based School in Jakarta, by giving them three self report questionnaires. This research use three measuring instruments, Inventory Classroom Environment, Creativity Attitude Survey, and School Engagement Measure. Thorugh regression analysis, the results showing the positive correlation between classroom climate and school engagement $(\mathrm{r}=.373 ; \mathrm{p}=.006)$ and creative attitude $(\mathrm{r}=.217 ; \mathrm{p}=.002)$. Through the mediation analysis, the results indicated that school engagement had a role as full mediator in relations between classroom climate with creative attitude in nature based school elementary students. This thing define that classroom climate in naturebased school will improve student's creative attitude when students involved emotionally, in cognitive and behavioral in school activity.
\end{abstract}

Keywords: classroom climate; creative attitude; mediator; nature-based school; school engagement.

\begin{abstract}
Abstrak
Penelitian ini bertujuan untuk melihat apakah pelibatan diri siswa berperan sebagai mediator dalam hubungan antara iklim kelas dengan sikap kreatif siswa di sekolah alam. Penelitian dilatarbelakangi oleh kebutuhan akan sikap kreatif untuk menghadapi tantangan masa depan. Salah satu cara untuk meningkatkan sikap kreatif dan pelibatan diri siswa adalah dengan menciptakan iklim kelas yang mendukung kebutuhan siswa tersebut. Sekolah alam merupakan salah satu sekolah alternatif yang menciptakan iklim kelas belajar aktif untuk mendorong pelibatan diri sehingga membuat siswa memiliki sikap kreatif. Penelitian dilakukan pada 129 siswa kelas 3-5 SD, dengan rentang usia 8-11 tahun di Sekolah Alam Indonesia. Pengambilan data penelitian menggunakan kuesioner lapor diri dengan tiga alat ukur yaitu Inventory Classroom Environment, Creativity Attitude Survey, dan School Engagement Measure. Melalui analisis regresi, hasil penelitian menunjukkan bahwa iklim kelas berkorelasi positif dan signifikan dengan pelibatan diri $(r=0,373 ; p=0,006)$ dan sikap kreatif siswa $(r=0,217$; $\mathrm{p}=0,002$ ). Melalui analisis mediasi, hasil olah data menunjukkan bahwa pelibatan diri berperan penuh sebagai mediator dalam hubungan antara iklim kelas dengan sikap kreatif siswa. Hasil analisis mediasi tersebut ditunjukkan dengan adanya penurunan nilai koefisien iklim kelas terhadap sikap kreatif, setelah pelibatan diri memediasi hubungan keduanya. Hal ini menunjukkan bahwa iklim kelas yang dirancang di sekolah alam akan meningkatkan sikap kreatif siswa apabila para siswanya melibatkan diri secara emosional, kognitif dan perilaku dalam proses pembelajaran.
\end{abstract}

Kata kunci: iklim kelas; mediator; pelibatan diri; sekolah alam; sikap kreatif.

\section{PENDAHULUAN}

Seiring dengan perkembangan zaman dan persaingan, Negara wajib merancang upaya untuk meningkatkan kualitas sumber daya manusia dalam menghadapi tantangan di masa yang akan datang (Munandar, 1999). 
Kualitas sumber daya manusia yang dibutuhkan adalah sumber daya manusia yang mampu melaksanakan pembangunan nasional secara inovatif, kreatif, produktif serta memiliki semangat kerja dan disiplin yang tinggi (Sagala, 2010). Salah satu aspek kualitas yang dibutuhkan dalam kehidupan saat ini adalah kreativitas, karena hampir setiap orang berbicara mengenai pentingnya kreativitas dikembangkan di sekolah, dituntut dalam pekerjaan dan diperlukan dalam pembangunan (Munandar, 1999).

Hal ini juga didukung oleh pendapat Bunyan (dalam Prihartono, 2011) yang menyatakan bahwa kunci keberhasilan seseorang tidak hanya tergantung dari tingkat kemampuan inteligensinya saja, namun didukung oleh kreativitas agar dapat menyesuaikan diri. Kreativitas merupakan hasil dari proses interaksi antara individu dan lingkungannya, lingkungan yang dapat meningkatkan kreativitas adalah melalui pendidikan (Munandar, 2004). Lingkungan pendidikan saat ini mulai berinovasi dengan menerapkan metode pembelajaran sesuai dengan kebutuhan siswa. Salah satu lingkungan pendidikan yang berinovasi adalah sekolah alam.

Sekolah alam merupakan salah satu sekolah alternatif yang bertujuan untuk mengubah paradigma pendidikan. Tujuan didirikannya sekolah alam adalah agar siswa merasa bahwa belajar adalah proses yang menyenangkan. Sekolah Alam merupakan sekolah yang memiliki konsep pendidikan berbasis alam (Komunitas Sekolah Alam, 2005). Alam sebagai sumber pengetahuan dan berfungsi sebagai ruang belajar, media, bahan ajar, serta objek pembelajaran. Konsep belajar di Sekolah Alam menerapkan sistem learning by doing, dimana siswa diajak untuk terjun langsung melihat secara nyata mengenai hal-hal yang berhubungan dengan materi pelajaran. Siswa diberikan kebebasan untuk bereksplorasi dengan bahan-bahan alamiah yang tersedia di Sekolah Alam seperti tanaman, hewan, dan sebagainya. Proses belajar di sekolah alam mengacu pada metode pembelajaran aktif (active learning). Metode pembelajaran aktif tersebut dilaksanakan melalui penciptaan suasana kelas yang berbeda dengan sekolah pada umumnya agar siswa lebih aktif dalam proses belajar seperti diskusi, mengemukakan pendapat, dan meningkatkan interaksi dengan guru maupun teman sebaya. Menurut Vygotsky (1978), pembelajaran akan semakin bermakna apabila melalui interaksi sosial dan membuat siswa lebih berperan aktif. Selain bertujuan untuk meningkatkan interaksi sosial, penciptaan suasana belajar di sekolah alam bertujuan untuk membuat siswa lebih mengalami langsung mengenai hal-hal yang dipelajarinya. Hal ini berarti bahwa penerapan metode pembelajaran di sekolah alam berbasis pengalaman (experiential learning).

Menurut Kolb (1984), experiential learning menekankan pada keinginan kuat dari dalam diri siswa untuk berhasil dalam belajarnya. Motivasi ini didasarkan pula pada tujuan yang ingin dicapai dan metode belajar yang dipilih. Keinginan untuk berhasil tersebut dapat meningkatkan tanggung jawab siswa terhadap perilaku belajarnya dan mereka akan merasa dapat mengontrol perilaku tersebut. Model experiential learning memberi kesempatan kepada siswa untuk memutuskan pengalaman apa yang menjadi fokus mereka, keterampilan-keterampilan apa yang ingin mereka kembangkan, dan bagaimana cara mereka membuat konsep dari pengalaman yang mereka alami tersebut. Hal ini berbeda dengan pendekatan belajar tradisional dimana siswa menjadi pendengar pasif dan hanya guru yang mengendalikan proses belajar tanpa melibatkan siswa. Penerapan ruang kelas di sekolah alam tersebut juga bertujuan agar siswa merasa tidak dibatasi dalam mengeksplorasi hal-hal sekitarnya sehingga diharapkan dapat mengembangkan berbagai kemampuan termasuk kreativitas.

Munandar (2004) mengatakan bahwa pada umumnya pendidikan di sekolah lebih berorientasi pada pengembangan kecerdasan 
(inteligensi) daripada pengembangan kreativitas. Hal ini yang menjadi fokus sekolah alam karena bertujuan tidak hanya mengembangkan sisi akademis siswa, namun juga kreativitas. Pengembangan kreativitas di sekolah alam dilaksanakan dengan menerapkan learner centered, dimana siswa lebih berperan aktif dalam pembelajaran. Penciptaan ruang kelas yang unik di sekolah alam bertujuan agar siswa dapat merasa lebih bebas untuk bereksplorasi hal-hal yang ingin dipelajarinya sehingga dapat mengasah kreativitasnya. Penelitian menunjukkan bahwa perkembangan optimal dari kreativitas berhubungan erat dengan cara mengajar (Munandar, 2004). Ketika belajar atas prakarsa sendiri dapat berkembang karena guru memberikan kepercayaan terhadap siswa untuk berani mengemukakan pendapat dan diberikan kesempatan untuk mengembangkan minatnya maka kemampuan kreatif akan tumbuh subur. Hal ini senada dengan pernyataan dari Robinson (2009) bahwa guru harus mengasah kreativitas siswa agar menjadi pribadi yang mempunyai pemikiran mandiri serta berani mengemukakan ide-ide yang inovatif yang dapat membantu siswa menghadapi persaingan di masa depan.

Kebutuhan akan kreativitas dalam penyelenggaraan pendidikan dewasa ini dirasakan sangat penting agar setiap peserta didik siap menghadapi tantangan saat ini dan tantangan di masa depan yang terus menerus berkembang. Menurut Semiawan (2005), belajar kreatif memiliki empat manfaat yaitu, membantu anak menjadi lebih berhasil secara mandiri, menciptakan kemungkinan untuk memecahkan masalah yang tidak mampu diramalkan yang akan timbul di masa depan, menimbulkan akibat besar dalam kehidupan seseorang dalam hal karir hingga kesehatan jiwa, menimbulkan kepuasan dan kesenangan yang besar. Secara lebih luas, belajar kreatif dapat menimbulkan terciptanya ide-ide baru, cara-cara baru dan menghasilkan sesuatu yang baru. Kreativitas memiliki dua ciri yaitu cara berpikir yang berhubungan dengan kognisi, proses berpikir yang meliputi kelancaran, kelenturan (fleksibilitas), orisinalitas dalam berpikir dan elaborasi (mengembangkan) suatu gagasan. Sedangkan ciri afektif atau sikap kreatif mencakup sikap atau perasaan yang meliputi rasa ingin tahu, bersifat imajinatif, merasa tertantang oleh kemajemukan, sifat berani mengambil resiko dan sifat menghargai. Menurut Munandar (1999), sikap kreatif merupakan ciri 'non aptitude traits' yang berkaitan dengan sikap, motivasi dan perasaan seseorang dalam menentukan prestasi kreatifnya agar bakat kreatif seseorang terwujud disebut dengan kreativitas aktualisasi diri. Menurut Mulyadi (1993) ditinjau dari pengertian $4 P$-kreativitas (Produk-Pribadi-Proses-Pendorong), sikap kreatif tampak ketika proses kreatif berkaitan dengan sikap dan perasaan individu yang bersibuk diri secara kreatif 'bermain' dengan gagasan-gagasan dalam pikirannya tanpa perlu menekankan terhadap apa yang dihasilkan dari proses kreatif itu, namun lebih menekankan dari sisi keasyikan dengan kegiatan yang penuh tantangan, dan imajinasi. Terdapat tujuh dimensi dalam sikap kreatif Menurut Munandar (2004), yaitu, keterbukaan terhadap pengalaman baru, kelenturan dalam sikap, kebebasan dalam ungkapan diri, menghargai fantasi, minat terhadap kegiatan kreatif, keyakinan terhadap kegiatan kreatif, penilaian bebas pengaruh dari orang lain.

Salah satu cara untuk meningkatkan sikap kreatif di lingkungan sekolah adalah dengan menciptakan iklim kelas yang merupakan penentu utama perilaku kelas dan kegiatan belajar mengajar (Tarmidi \& Wulandari, 2005). Siswa seharusnya merasakan bahwa ruang kelas tidak hanya ruangan untuk meningkatkan segi intelektual, namun juga meningkatkan kemampuan sosial, emosional dan fisik. Iklim kelas seringkali diartikan sebagai lingkungan belajar atau atmosfir, suasana, lingkungan pergaulan dan hubungan timbal balik. Pengaruh dari iklim kelas pada siswa dan guru dapat menguntungkan atau menghambat proses pembelajaran (Adelman \& Taylor, 2005). Menurut Sinclair dan Fraser (2002), iklim kelas dapat diartikan sebagai 
lingkungan kelas yang mencakup persamaan persepsi antara guru dan siswa. Iklim kelas merupakan salah satu kebutuhan yang penting dimiliki oleh setiap sekolah pada saat ini karena membuat siswa saling berinteraksi dengan lingkungannya dan teori pembelajaran sosial mengatakan bahwa lingkungan kelas merupakan pengaruh terbesar bagi sikap seseorang.

Terdapat lima dimensi dalam iklim kelas, yaitu kerja sama, dimensi yang ingin mengukur sejauh mana siswa dapat bekerjasama dengan siswa lainnya selama proses belajar mengajar berlangsung di kelas. contoh aitem dalam dimensi ini adalah "saya mengerjakan tugas dengan baik bersama murid lainnya di kelas." Dimensi selanjutnya dukungan guru (teacher support), yaitu dimensi yang ingin mengukur sejauh mana guru memberikan bantuan, dukungan dan memiliki keterlibatan dengan siswa. Contoh aitem dalam dimensi ini adalah "guru saya ingin agar saya dapat mengerjakan tugas dengan baik di kelas." Orientasi tugas (task orientation), yaitu dimensi yang ingin mengukur sejauh mana suatu kelas harus tetap mengerjakan dan menyelesaikan suatu tugas. Contoh aitem dalam dimensi ini adalah "saya memperhatikan ketika di kelas." Keterlibatan (involvement), yaitu dimensi yang ingin mengukur sejauh mana siswa berpartisipasi aktif di dalam kelas seperti diskusi. Contoh aitem dalam dimensi ini adalah "saya menjawab pertanyaan ketika di kelas." Keadilan (equity), yaitu dimensi yang ingin mengukur sejauh mana guru memperlakukan siswa secara adil termasuk dalam memberikan pujian dan pertanyaan. Contoh aitem dalam dimensi adalah "guru saya berlaku adil terhadap semua murid di kelas."

Suasana kelas yang secara tidak langsung mengabaikan pendapat atau sudut pandang siswa akan membuat siswa tidak berempati terhadap guru yang gagal dalam memberikan kebebasan berpendapat pada siswa (Huston \& DiPietro, 2007). Pembatasan pada suasana kelas seperti ini akan memberikan dampak negatif pada motivasi untuk belajar dan mengembangkan kemampuan kognitif siswa (Ambrose, Bridges, DiPietro, Lovet, \& Mayer, 2010). Keadaan psikologis dan hubungan sosial yang dibentuk di dalam kelas tersebut merupakan salah satu upaya guru dalam mendukung proses pembelajaran siswa yang merupakan salah satu faktor kontekstual dalam meningkatkan pelibatan diri siswa di kelas (Fredricks, Blumenfeld \& Paris, 2004). Pelibatan diri merupakan intensitas dan kualitas emosional dari keterlibatan siswa secara aktif selama aktivitas pembelajaran (Fredricks, dkk, 2004). Pelibatan diri merupakan konstruk yang merefleksikan antusiasme siswa untuk berpartisipasi dalam suatu tugas atau proses pembelajaran yang dapat diukur dan diamati melalui usaha, perhatian, partisipasi verbal, ketekunan, dan kesenangan yang diperlihatkan siswa selama proses belajar (Veiga, Reeve, Bahia, Galvao, Tagarro, \& Forno, 2014).

Terdapat tiga dimensi pelibatan diri yaitu pelibatan diri secara perilaku, menurut Fredericks, Blumenfeld dan Paris (2004), meliputi bagaimana siswa mengerjakan tugas dan mematuhi peraturan di kelas. Siswa terlibat secara emosi ketika siswa memasukkan minat (interest), nilai (value), dan emosi selama aktivitas pembelajaran. Pelibatan diri secara emosi mengacu pada reaksi afektif yang menyertai aktivitas pembelajaran siswa dalam kelas seperti adanya minat, kebosanan, kesenangan, kesedihan dan kecemasan. Serta dimensi pelibatan diri secara kognitif (cognitive engagement), menurut Fredericks, dkk (2004), merupakan penggunaan strategi belajar yang meliputi rehearsal, summarizing, dan elaboration untuk mengingat, mengatur dan memahami materi pembelajaran dan penggunaan strategi metakognitif untuk merencanakan, memonitor dan mengevaluasi kognisi selama menyelesaikan tugas belajar.

Kreativitas hendaknya dikembangkan sejak usia dini karena pertumbuhan sel jaringan 
otak pada usia 0-4 tahun berkembang 50\%, hingga usia 8 tahun mencapai $80 \%$ (Bloom, 2003). Dengan demikian wajar apabila pengembangan kreativitas sangat efektif apabila diterapkan pada siswa Sekolah Dasar karena merupakan fase persiapan pembelajaran di masa depan (Robinson, 2009). Jenjang Sekolah Dasar merupakan fase dimana anak memiliki rasa ingin tahu yang tinggi serta tanggap terhadap dunia sekitarnya. Selain itu, karakteristik anak Sekolah Dasar tidak terlepas dari dunia bermain, sehingga akan lebih baik apabila kebiasaan bermain tersebut dapat menstimulus kreativitas anak (Muqodas, 2015). Jenjang usia Sekolah Dasar pada umumnya berkisar antara 7-11 tahun, dimana pada tahapan tersebut termasuk dalam tahapan perkembangan operasional konkret (Piaget dalam Papalia, 2009). Melalui tahapan perkembangan operasional konkret pada siswa Sekolah Dasar tersebut, maka metode pembelajaran aktif (acitve learning) dapat dikatakan sesuai dengan karakter siswa. Melalui pembelajaran aktif yang membuat siswa untuk lebih terlibat aktif dalam proses belajar dapat mendukung tahap berpikir operasional konkretnya.

Iklim kelas merupakan tempat dimana siswa dan guru berinteraksi satu sama lain dengan menggunakan beberapa sumber informasi dalam usaha pencarian ilmu saat aktifitas belajar berlangsung. Peranan guru dalam menciptakan iklim kelas juga merupakan salah satu faktor siswa untuk lebih melibatkan diri dalam proses belajar sehingga dapat terlihat antusiasme siswa untuk berpartisipasi dalam suatu tugas atau proses pembelajaran yang dapat diukur dan diamati melalui usaha, perhatian, partisipasi verbal, ketekunan, dan kesenangan yang diperlihatkan siswa selama proses belajar.

Pelibatan diri siswa dilihat dari tiga aspek yaitu kognitif, emosional dan perilaku, aspek kognitif merupakan aspek yang meliputi proses berpikir siswa yang didalamnya terdapat rasa ingin tahu yang tinggi yang merupakan dimensi dari kreativitas. Penciptaan iklim kelas yang menyenangkan dilakukan di salah satu sekolah swasta yaitu Sekolah Alam karena suasana kelas di sekolah alam menerapkan belajar aktif yang bertujuan agar siswa lebih mengekspresikan ide-ide, pengetahuan dan lebih bereksperimen melalui peralatan sederhana yang terdapat di Sekolah Alam tersebut. Melalui penciptaan iklim kelas tersebut apakah siswa dapat melibatkan diri secara kognitif, emosional dan perilaku yang nantinya dapat mengasah sikap kreatif siswa tersebut.

\section{METODE}

Metode penelitian menggunakan tipe kuantitatif dengan teknik pengambilan sampel yang non probability sampling atau non random sampling. Partisipan penelitian terdiri dari 129 siswa Sekolah Dasar Sekolah Alam Indonesia kelas 3-5.

Alat ukur yang digunakan berupa kuesioner lapor diri (self-report questionnare) yang terdiri dari tiga alat ukur. Alat ukur iklim kelas menggunakan alat ukur Inventory of Classroom Environment (ICE) yang disusun oleh Sinclair \& Fraser (2002). Alat ukur ICE tersebut terdiri dari 25 aitem $(\alpha=0,841)$, salah satu contoh butir aitem adalah "aku mengerjakan tugas kelompok di kelas." Alat ukur sikap kreatif menggunakan Creativity Attitude Survey (CAS) yang disusun oleh Schaefer (1971) dan dikembangkan kembali oleh Dow (2004). Alat ukur CAS terdiri dari 23 aitem $(\alpha=0,468)$, salah satu contoh butir aitem dalam alat ukur tersebut adalah "Aku biasanya mencoba cara baru dalam melakukan sesuatu daripada menggunakan cara yang sering dipakai." Alat ukur pelibatan diri menggunakan School Engagement Measure-McArthur yang disusun oleh Fredricks, dkk (2005). Alat ukur School Engagement Measure-McArthur terdiri dari 12 aitem $(\alpha=0,762)$, salah santu contoh butir aitemnya adalah "Aku bersemangat mengerjakan tugas yang ada di 
sekolah." Terdapat tiga tahap pengujian alat ukur, yang pertama melakukan adaptasi alat ukur melalui proses penerjemahan, uji keterbacaan aitem alat ukur, serta uji coba alat ukur yang dilakukan di tempat yang berbeda dengan pengambilan data penelitian sesungguhnya namun memiliki kriteria populasi yang sama. Uji coba alat ukur diberikan kepada empat puluh siswa kelas 35 di salah satu cabang sekolah alam di Depok.

Teknik analisis data dalam penelitian ini dibantu dengan program SPSS (Statistical Package for Social Science) dan program Mplus Editor. Analisa data mencakup statistik deskriptif, untuk melihat gambaran subjek penelitian berdasarkan usia, jenis kelamin dan kelas. Selain itu, statistik deskriptif juga digunakan untuk melihat gambaran variabel penelitian. Analisa mediasi, untuk menguji hipotesis penelitian. Guna menguji hal tersebut, digunakan pearson correlation dan multiple regression. Hasil yang diperoleh merupakan hasil utama penelitian. Serta independent sample t-test, untuk menguji perbedaan dua kelompok, yaitu antara siswa laki-laki dan perempuan serta usia $8,9,10$, dan 11 .

\section{HASIL DAN PEMBAHASAN}

Proses pengambilan data diberikan kepada 129 siswa kelas 3-5 di Sekolah Alam Indonesia Pusat, dengan jumlah paling banyak pada kelas 5 dan didominasi oleh siswa perempuan. Rentang usia subjek penelitian berkisar antara usia 8-11 tahun, sedangkan yang paling banyak berada pada usia 9 tahun. Hasil penelitian menunjukkan bahwa terdapat hubungan yang positif dan signifikan antara iklim kelas dengan pelibatan diri. Hal ini berarti semakin tinggi skor iklim kelas siswa maka semakin tinggi pula skor pelibatan diri siswa, nilai 0,192 menunjukkan koefisien korelasi dan dapat disimpulkan bahwa berada pada hubungan sangat rendah karena berada pada rentang $0,00-0,199$. Selain itu, terdapat hubungan yang positif dan signifikan antara iklim kelas dengan sikap kreatif yang berarti bahwa semakin tinggi skor iklim kelas maka semakin tinggi skor sikap kreatif siswa. Variabel pelibatan diri juga berkorelasi positif dan signifikan dengan sikap kreatif siswa. Hasil perhitungan penelitian dapat dilihat pada tabel 1 .

Untuk menguji apakah variabel Pelibatan Diri sebagai variabel yang memediasi hubungan antara Iklim Kelas dengan Sikap Kreatif, disyaratkan analisisnya memenuhi tiga tahapan yang disampaikan oleh Baron dan Kenny (1986) yaitu, 1.) Melakukan regresi variabel bebas (Iklim Kelas) dengan variabel terikat (Sikap Kreatif). Jalur hubungan dinotasi huruf c. Dari hasil estimasi tersebut nilai c disyaratkan hubungannya bersifat signifikan. 2.) Membuat estimasi hubungan variabel bebas (Iklim kelas) dengan mediator (Pelibatan Diri). Jalur hubungan dinotasi huruf a. Nilai estimasi a juga disyaratkan hubungan signifikan. 3.) Melakukan estimasi hubungan Iklim Kelas dan Pelibatan Diri secara bersama-sama dengan Sikap Kreatif.

Tabel 1.

Koefisien Hubungan Antar Variabel

\begin{tabular}{|c|c|c|c|c|}
\hline Variabel penelitian & & Iklim kelas & Pelibatan Diri & Sikap kreatif \\
\hline & $\mathrm{r}$ & 1 & $0,192 * *$ & $0,217 * *$ \\
\hline Iklim kelas & Sig. (2-tailed) & & 0,006 & 0,002 \\
\hline Pelibatan Diri & $\begin{array}{l}\mathrm{r} \\
\text { Sig. (2-tailed) }\end{array}$ & $\begin{array}{l}0,192 * * \\
0,006\end{array}$ & 1 & $\begin{array}{l}0,484 * * \\
0,000\end{array}$ \\
\hline Sikap Kreatif & $\begin{array}{l}\text { r } \\
\text { Sig. (2-tailed) }\end{array}$ & $\begin{array}{l}0,217 * * \\
0,002\end{array}$ & $\begin{array}{l}0,484 * * \\
0,000\end{array}$ & 1 \\
\hline
\end{tabular}

**. Korelasi signifikan pada $\mathrm{p}<0,01$ (2-tailed). 
Jalur hubungan dinotasi huruf c' dan b. Dalam model 3, Agar Pelibatan Diri dikatakan sebagai variabel yang memediasi hubungan antara Iklim Kelas dan Sikap Kreatif, disyaratkan variabel Pelibatan Diri memiliki hubungan yang signifikan dengan Sikap Kreatif bilamana variabel Iklim Kelas dilibatkan dalam persamaan regresi. Hasil pengujian mediasi tersebut secara lengkap disajikan pada tabel 2.

Langkah pertama untuk menguji hubungan variabel mediasi pelibatan diri adalah dengan pengujian hubungan variabel bebas iklim kelas dan variabel terikat sikap kreatif. Hasilnya menunjukan bahwa variabel iklim kelas berhubungan signifikan ( $\mathrm{c}=0,217$, $\mathrm{SE}=0,023, \mathrm{t}=3,138)$ dengan variabel sikap kreatif. Dengan demikian persyaratan pada kriteria pertama terpenuhi dalam penelitian ini yang menyatakan bahwa iklim kelas berhubungan secara signifikan dengan sikap kreatif.

Langkah kedua adalah menguji pengaruh variabel independen iklim kelas pada variabel mediator pelibatan diri. Dari tabel 2 diketahui bahwa iklim kelas berhubungan secara signifikan $(\mathrm{a}=0,373, \mathrm{SE}=0,101, \mathrm{t}=$ 5,668) dengan pelibatan diri. Dengan demikian dapat disimpulkan bahwa kriteria kedua terpenuhi dalam penelitian ini yang menyatakan bahwa iklim kelas berhubungan secara signifikan dengan pelibatan diri. Langkah ketiga adalah melakukan pengujian pengaruh variabel mediator pelibatan diri dengan variabel terikat sikap kreatif demikian juga variabel iklim kelas pada variabel terikat sikap kreatif. Pada langkah ke tiga, proses regresi tidak bisa dilakukan secara sendiri dari variabel pelibatan diri ke sikap kreatif akan tetapi dalam proses regresinya harus mengikutsertakan variabel iklim kelas. Dengan kata lain prosesnya adalah meregresikan variabel iklim kelas dan pelibatan diri secara bersama-sama sebagai variabel bebas dengan variabel terikat sikap kreatif. Hasil regresi bersama-sama pada Model 3 menunjukan bahwa pelibatan diri memiliki hubungan yang signifikan $(b=$ $0,546, \mathrm{SE}=0,014, \mathrm{t}=8,545)$ dengan variabel terikat sikap kreatif dengan demikian kriteria ketiga terpenuhi. Berdasarkan perhitungan tersebut dapat disimpulkan bahwa variabel pelibatan diri adalah variabel yang memediasi hubungan antara iklim kelas dan sikap kreatif. Dengan demikian persyaratan ketiga terpenuhi dalam penelitian ini yang menyatakan pelibatan diri berhubungan secara signifikan dengan sikap kreatif. Untuk melihat apakah mediasi yang disebutkan tersebut merupakan mediasi sebagian (partial) atau mediasi penuh (full mediation) dapat diuji dengan melihat nilai koefisien $\mathrm{c}$ dan c' dari tabel 1.

Tabel 2.

Hubungan iklim kelas dan sikap kreatif yang dimediasi oleh pelibatan diri

\begin{tabular}{lccccc}
\hline Variabel & Koefisien & SE & t-value & Sig. & $\mathrm{R}^{2}$ \\
\hline $\begin{array}{l}\text { Model 1: } \\
\text { Iklim Kelas } \rightarrow\end{array}$ & $\mathrm{c}=0,217$ & 0,023 & 3,138 & 0,002 & 0,047 \\
Sikap Kreatif & & & & & 0,139 \\
\hline $\begin{array}{l}\text { Model 2: } \\
\text { Iklim Kelas } \rightarrow \\
\text { Pelibatan Diri }\end{array}$ & $\mathrm{a}=0,373$ & 0,101 & 5,668 & 0,000 & \\
\hline $\begin{array}{l}\text { Model 3 : } \\
\begin{array}{l}\text { Pelibatan Diri } \rightarrow \text { Sikap } \\
\text { Kreatif }\end{array}\end{array}$ & & & & \\
$\begin{array}{l}\text { Iklim Kelas } \rightarrow \text { Sikap } \\
\text { Kreatif }\end{array}$ & $\mathrm{b}=0,546$ & 0,014 & 8,545 & 0,000 & 0,304 \\
& & & & & \\
\end{tabular}




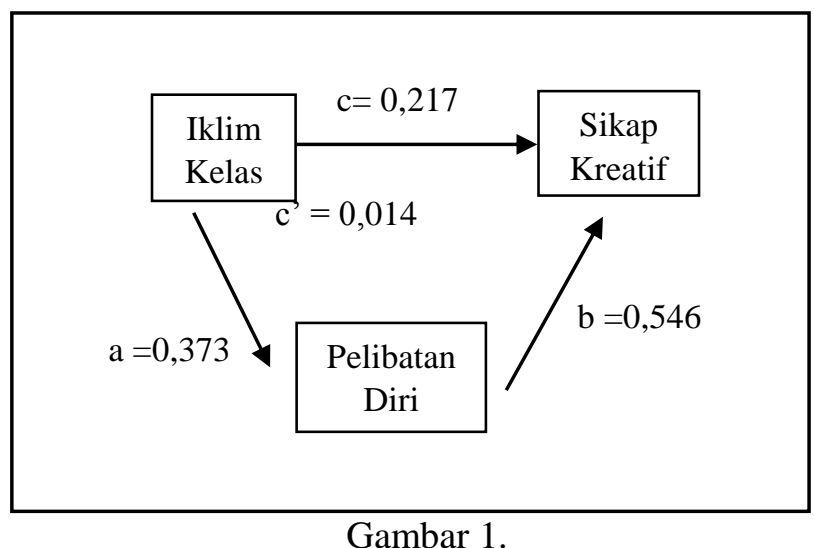

Koefisien Jalur Estimasi antar Variabel Penelitian

Pada tabel tersebut nilai c adalah 0,217 sedangkan nilai c' adalah 0,014 sehingga nilai koefisien jalur yang menghubungkan iklim kelas ke variabel sikap kreatif mengalami penurunan nilai dari 0,217 menjadi 0,014 setelah variabel pelibatan diri memediasi hubungan keduanya. Dengan demikian terjadi penurunan nilai koefisien dari c menjadi c' $\left(c^{\prime}(0,014)<\mathrm{c}(0,217)\right.$, namun koefisien pada jalur c' tidak signifikan dan terjadi penurunan nilai dari c menjadi c'. Dengan demikian model mediasi yang terbentuk adalah mediasi penuh ( full mediation). Model yang dikembangkan oleh peneliti didukung oleh data, sehingga dapat disimpulkan bahwa pelibatan diri sangat berperan dalam hubungan antara iklim kelas dengan sikap kreatif siswa. Gambar 1 menunjukkan koefisien jalur estimasi antar variabel penelitian.

Melalui analisa data yang telah dilakukan, hasil penelitian yang pertama diketahui bahwa iklim kelas memiliki hubungan yang positif dan signifikan dengan sikap kreatif.

Hal ini menunjukkan bahwa semakin tinggi iklim kelas yang dirasakan siswa maka akan semakin tinggi sikap kreatif yang dimiliki siswa. Penelitian ini didukung oleh teori menurut Munandar (2004) yang menyatakan bahwa kreativitas hendaknya meresap dalam kurikulum dan iklim kelas. Faktor-faktor iklim kelas yang dimaksud mencakup menerima keunikan individu, memberikan kesempatan untuk mengemukakan ide atau pendapatnya masing-masing sesuai dengan dimensi-dimensi dalam iklim kelas menurut menurut Tricket dan Moos (1974) yaitu dimensi afiliasi (affiliation) yaitu hubungan antar individu di dalam kelas serta penerimaan kelompok di kelas. Dimensidimensi iklim kelas menurut Tricket dan Moos (1974) tersebut sejalan dengan dimensi iklim kelas menurut Sinclair dan Fraser (2002), dimana dimensi kerja sama memiliki kesamaan pengertian dengan dimensi afiliasi yaitu hubungan antar individu di dalam kelas serta penerimaan kelompok.

Dimensi kerja sama dapat dikatakan berhubungan dengan salah satu ciri sikap kreatif menurut Munandar (2004) yaitu sikap saling menghargai. Sikap saling menghargai tersebut ditunjukkan dengan menghargai bimbingan dan pengarahan dalam hidup, menghargai kemampuan dan bakat masingmasing individu yang sedang berkembang. Oleh karena itu, iklim kelas yang di dalamnya terdapat kerja sama antar siswa diharapkan dapat membuat siswa lebih memiliki sikap saling menghargai satu sama lain. Iklim kelas yang diterapkan di Sekolah alam lebih dominan untuk melakukan diskusi dan kerja kelompok selama pembelajaran, hal ini bertujuan untuk meningkatkan kerja sama antar siswa agar siswa berani mengemukakan pendapatnya serta belajar menghargai pendapat orang lain. Iklim kelas yang diciptakan untuk mendorong kerja sama antar siswa juga bertujuan untuk pembelajaran kooperatif. 
Menurut Vygotsky (1978), pembelajaran kooperatif bertujuan agar siswa saling membantu satu sama lain. Proses pembelajaran pada siswa terjadi saat siswa belajar dalam zona perkembangan proksimal mereka. Tugas-tugas dalam zona perkembangan proksimal adalah sesuatu yang masih belum dapat dikerjakan seorang anak sendirian tetapi dapat dikerjakan dengan bantuan teman yang lebih kompeten atau orang dewasa.

Melalui penelitian dan olah data, disimpulkan bahwa terdapat hubungan yang positif dan signifikan antara iklim kelas dengan pelibatan diri. Hal ini menunjukkan bahwa apabila sekolah menerapkan iklim kelas yang baik maka akan membuat siswanya lebih melibatkan diri dalam setiap proses pembelajaran. Menurut Fredricks, dkk (2004), keadaan dan hubungan sosial yang dibentuk di dalam kelas merupakan salah satu upaya guru dalam mendukung proses pembelajaran siswa yang merupakan salah satu faktor kontekstual dalam meningkatkan pelibatan diri siswa di kelas. Salah satu dimensi iklim kelas menurut Sinclair dan Fraser (2002), adalah involvement atau keterlibatan. Hal ini terkait dengan sejauh mana siswa berpartisipasi aktif di dalam kelas. Penerapan iklim kelas di Sekolah alam yang di dalamnya terdapat kerja sama dan dukungan guru bertujuan untuk meningkatkan keaktifan siswa selama di kelas yang terkait dengan pelibatan diri. Pelibatan diri siswa di kelas mencakup tiga dimensi yaitu secara perilaku, kognitif dan emosional (Fredericks, dkk, 2004). Ketiga dimensi dalam pelibatan diri tersebut tidak hanya membuat siswa aktif pada bidang akademis, namun juga melibatkan diri secara keseluruhan. Oleh karena itu, apabila iklim kelas yang diterapkan mencakup keterlibatan, maka akan menghasilkan siswa yang melibatkan diri secara keseluruhan. Siswa akan merasa bahwa belajar menjadi hal yang menyenangkan karena penciptaan iklim kelas tersebut.
Hasil penelitian menunjukkan bahwa iklim kelas secara signifikan berhubungan dengan sikap kreatif. Berdasarkan hasil tersebut, guru memiliki peran penting untuk menerapkan iklim kelas yang lebih meningkatkan kerja sama (dengan cara diskusi), pelibatan diri serta memberikan dukungan kepada siswa agar mengasah sikap kreatifnya. Pelibatan diri berperan sebagai mediator hubungan iklim kelas dengan sikap kreatif siswa. Berdasarkan hal tersebut, guru harus memastikan bahwa iklim kelas yang diterapkan di sekolah dapat mendukung pelibatan diri siswa baik secara perilaku, emosional dan kognitif agar siswa dapat lebih melibatkan diri dalam setiap proses belajar, tidak merasa terpaksa dan diharapkan muncul rasa ingin tahu siswa yang berkaitan dengan sikap kreatif. Berdasarkan hasil penelitian ini, bahwa peran iklim kelas sangat penting dalam meningkatkan pelibatan diri dan sikap kreatif siswa. Oleh karena itu, akan lebih baik apabila pihak sekolah mengadakan pelatihan untuk menerapkan iklim kelas yang lebih menarik lagi untuk membuat siswa lebih terlibat dalam setiap proses pembelajaran dan mengasah sikap kreatifnya.

\section{SIMPULAN}

Kesimpulan dari penelitian ini menunjukkan bahwa pelibatan diri memediasi hubungan antara iklim kelas dengan sikap kreatif. Hal ini menunjukkan bahwa iklim kelas dan sikap kreatif berhubungan secara tidak langsung namun melalui pelibatan diri. Penerapan iklim kelas yang diterima siswa selama di sekolah akan membuat siswa memiliki sikap kreatif apabila siswa melibatkan diri dalam proses belajarnya. Penerapan metode-metode iklim kelas yang dirancang oleh guru tidak akan berjalan efektif apabila siswa tidak melibatkan diri dalam setiap prosesnya sehingga nantinya akan membuat siswa memiliki sikap kreatif. Pelibatan diri dalam iklim kelas sangat penting karena mencakup perilaku, emosi dan kognitif. Pelibatan diri secara perilaku 
meliputi usaha, perhatian, inisiatif dan partisipasi. Apabila iklim kelas di Sekolah alam diterapkan dengan meningkatkan kerja sama, dukungan dari guru dan meningkatkan keterlibatan siswa maka siswa akan lebih meningkatkan pelibatan dirinya secara perilaku.

\section{DAFTAR PUSTAKA}

Adelman, H.S. \& Taylor, L. (2005): Classroom climate. In: Lee, S.W., Lowe, P.A. \& Robinson E. (Eds.), Encyclopedia of school psychology. Thousand Oaks, CA:Sage.

Ambrose, S., Bridges, M., DiPietro, M., Lovet, M., \& Mayer, R. (2010). How learning works: Seven research -based principles for smart teaching. San Fransisco: Jossey-Bass.

Baron, R. M. \& Kenny, D. A. (1986). The moderator-mediator variable distinction in social psychological research: Conceptual, strategic, and statistical considerations. Journal of Personality and Social Psychology, 51(6), 1173-1182.

Bloom, B. S. (2003). Taxonomy of educational objective: Handbook 7. cognitive domain. New York: Longman.

Dow, G. (2004). Creativity Test: Creative Attitude Survey (Schaeffer, 1971). Diakses dari http://www.indiana.edu/ bobweb/andout/d13.cas.htm.Diakses pada tanggal 13 Maret 2016.

Fredricks, J., Blumenfeld, P., \& Paris, A. (2004). School engagement: Potential of the concept, state of Evidence. Review of Educational Research, Vol. 74, 59-109.
Huston, T. A., \& DiPietro, M. (2007). In the eye of the storm: Students perceptions of helpful faculty actions following a collective tragedy. In D. R. Robertson \& L. B. Nilson (Eds.) To Improve the Academy. Vol 25. Resources for faculty, instructional, and organizational development (pp. 207-224). Bolton, MA: Anker.

Kolb, D. (1984). Experiential learning: Experience as the source of learning and development. Upper Saddle River, NJ: Erlbaum.

Komunitas Sekolah Alam. (2005). Menemukan sekolah yang membebaskan. Tangerang: Kawan Pustaka.

Munandar, U. (1999). Kreativitas dan keberbakatan; strategi mewujudkan potensi kreatif dan bakat. Jakarta: PT. Gramedia Pustaka.

Munandar, U. (2004). Pengembangan kreativitas anak berbakat. Jakarta: PT. Rineka Cipta.

Mulyadi, S. (1993). Kreativitas dan bermain. Jakarta. Disertasi Tidak Dipublikasikan. Program Pascasarjana Fakultas Psikologi Universitas Indonesia.

Muqodas, I. (2015). Mengembangkan kreativitas siswa sekolah dasar. Metodik Didaktik, 9(2)

Papalia, O., \& Feldman, D. R. (2009). Human development (Perkembangan manusia edisi 10 buku 1). (Penerjemah Brian M). Jakarta: Salemba Humanika.

Prihartono, I. (2011). Pola asuh, persepsi tentang iklim kelas dan sikap kreatif anak sekolah alam kandank jurang doank. Skripsi Tidak Dipublikasikan. 
Jakarta. Universitas Islam Negeri Syarif Hidayatullah

Robinson, K. (2009). The element. New York: Penguin Group.

Sagala, C. (2010). Hubungan antara persepsi terhadap iklim kelas dengan kreativitas siswa SMA Salam Kudus Medan. Skripsi Tidak Dipublikasikan. Medan. Universitas Sumatera Utara

Semiawan, C. R. (2005). Mengembangkan kreativitas. Bandung: Remaja Rosdakarya.

Sinclair, B. B., \& Fraser, B. J. (2002). Changing classroom environment in urban middle schools. Learning Environment Research 5: 301-328.
Tarmidi, H., \& Wulandari, L. (2005). Prestasi belajar ditinjau dari persepsi siswa terhadap iklim kelas pada siswa akselerasi. Jurnal Psikologia Vol. 1.

Tricket \& Moos. (1974). Classroom environment scale manual. Palo Alto, CA: Consulting Psychology Press.

Veiga, F., Reeve, J., Bahia, S., Galvao, D., Tagarro, M., \& Forno, L. (2014). Student's engagement in school, giftedness and creativity; $A$ literature review. Lisbon: Universidade de Lisbon.

Vygotsky, L. (1978). Mind and Society. Cambridge: Harvard University Press. 